\title{
Aplikasi E-Commerce Penjualan Dan Pemesanan Sparepart Berbasis Web Menggunakan Framework Codeigniter Pada Toko Hikmah Motor
}

\author{
Rerin Wulandari ${ }^{*}$, Mochammad Faid1 ${ }^{2}$, Cahyuni Novia ${ }^{3}$ \\ 1,2,3 Prodi Informatika Fakultas Teknik Universitas Nurul Jadid \\ Karanganyar Paiton Probolinggo \\ e-mail: ${ }^{1 *}$ rerin.wulandari@gmail.com, ${ }^{2}$ mfaid@unuja.ac.id, ${ }^{3}$ vhie771108@gmail.com
}

\begin{abstract}
Abstrak
Toko hikmah motor adalah toko yang menjual sparepart motor yang sudah mempunyai banyak pelanggan. Pelayanan penjualan dan pemesanan sparepart di toko ini masih mengalami banyak kendala, yaitu dimana customer hanya bisa melakukan pemesanan barang melalui whatsapp atau dengan cara datang langsung ke toko. Biasanya customer datang dengan membawa catatan yang berisi mengenai barang yang ingin di pesan, kemudian customer tersebut menunggu pesanannya hingga selesai bahkan sampai ada customer yang pulang terlebih dahulu, dan kembali lagi untuk mengambil pesanannya. Hal ini mengakibatkan customer harus bolak balik ke toko dan dapat mengakibatkan customer merasa kecewa terhadap pelayanan yang ada, karena tidak adanya infomasi yang akurat dari pihak toko kepada customer mengenai ketersediaannya sapepart. Peneliti memberikan solusi dengan membuat aplikasi ecommerce penjualan dan pemesanan sparepart berbasis web menggunakan framework codeigniter. Dengan adanya aplikasi ini dapat membantu memudahkan pihak toko dalam melakukan penjualan juga pelayanan, dan dapat membantu customer dalam melakukan pemesanan sparepart secara online. Berdasarkan hasil penelitian yang dilakukan dengan menggunakan pengujian internal dan eksternal diperoleh nilai $75 \%$ yang dapat disimpulkan bahwa aplikasi tersebut dikategorikan baik dan layak untuk digunakan dalam pelaksaan penjualan dan pemesanan sparepart secara online.
\end{abstract}

Kata kunci: e-commerce, sparepart, web, customer, pemesanan

\begin{abstract}
Motor wisdom shop is a shop that sells motorcycle spare parts that already have many customers. Sales and ordering services for spare parts at this store are still experiencing many obstacles, namely where customers can only order goods via whatsapp or by coming directly to the store. Usually the customer comes with a note containing the item he wants to order, then the customer waits for the order to finish, even until a customer goes home first, and comes back to take his order. This results in the customer having to go back and forth to the store and can result in the customer feeling disappointed with the existing service, because there is no accurate information from the store to the customer regarding the availability of spare parts. Researchers provide solutions by creating web-based e-commerce sales and spare parts ordering applications using the CodeIgniter framework. With this application, it can help make it easier for the store to make sales as well as service, and can assist customers in ordering spare parts online. Based on the results of research conducted using internal and external tests obtained a value of $75 \%$ which can be concluded that the application is categorized as good and feasible to use in the implementation of sales and ordering spare parts online.
\end{abstract}

Keywords:e-commerce, sparepart, web, customer, booking 


\section{PENDAHULUAN}

Perkembangan dunia otomotif dimasyarakat semakin pesat, hal ini terlihat berasal banyaknya kendaraan motor serta mobil sebagai akibatnya banyak pembuat ataupun perseorangan tertarik berbisnis dibidang pemugaran otomotif dan bengkel [1]. Bengkel artinya tempat (bangunan atau ruangan) buat perawatan/pemeliharaan, perbaikan, modifikasi alat serta mesin, tempat pembuatan bagian mesin dan perakitan mesin [2]. Bengkel pula melakukan usaha penjualan suku cadang guna melengkapi kebutuhan penggantian suku cadang kendaraan yg rusak" [3].

Toko hikmah motor adalah toko yang menjual sparepart motor, yang sudah mempunyai banyak pelanggan. Pelayanan penjualan dan pemesanan sparepart di toko ini masih mengalami banyak kendala, dimana customer hanya bisa melakukan pemesanan barang melalui whatsapp atau dengan cara datang langsung ke toko hikmah motor [4]. Biasanya customer datang dengan membawa catatan yang berisi mengenai barang yang ingin di pesan, kemudian customer tersebut menunggu pesanannya hingga selesai.

Kadang customer pulang terlebih dahulu dan kembali lagi untuk mengambil pesanannya. Hal ini mengakibatkan customer harus bolak balik ke toko. masalah seperti ini juga dapat mengakibatkan customer merasa kecewa terhadap adanya pelayanan, karena tidak adanya infomasi yang akurat dari pihak toko terhadap customer. Juga sering terdapat kesalahan customer dalam menulis catatan barang apa saja yang ingin dipesan membuat pihak toko bingung dan salah dalam mengambil barang. Sehingga memakan waktu yang cukup lama. Hal ini juga dapat mempengaruhi pelanggan untuk beralih ke toko lain.

Berdasarkan uraian permasalahan yang dihadapi oleh Toko Hikmah Motor, maka dibutuhkan aplikasi ecommerce penjualan dan pemesanan sparepart berbasis web untuk memudahkan pelanggan dalam melakukan pemesanan, juga mempermudah pihak toko dalam proses pelayanan.

Perkembangan teknologi internet yang sangat cepat dari tahun ke tahun dan sangat bermanfaat dalam segala bidang penjualan [5]. Sebelum ada internet untuk menjual suatu produk, penjual masih menggunakan cara tradisional yaitu dengan menjual atau memesan secara langsung dari toko. Tetapi dengan adanya internet, penjual dapat memperkenalkan sekaligus menjual produknya melalui website.

Penelitian ini akan membuat Aplikasi E-Commerce penjualan dan pemesanan sparepart berbasis Web dengan menggunakan Framework Codeigniter pada Toko Hikmah Motor. Dengan menggunakan aplikasi ini diharapkan menjadi suatu program yang dapat membantu pengguna dalam melakukan penjualan atau pemesanan sparepart [6] di toko Hikmah Motor. 


\section{METODE PENELITIAN}

Dalam penelitian disini yang akan di lakukan tahapan-tahapan aktifitas aktifitas dimana tahapan-tahapan tersebut merupakan cara untuk mencapai tujuan dalam penelitian [7], tahapan dalam aktifitas ini dapat dilihat dari gambar 1 berikut:

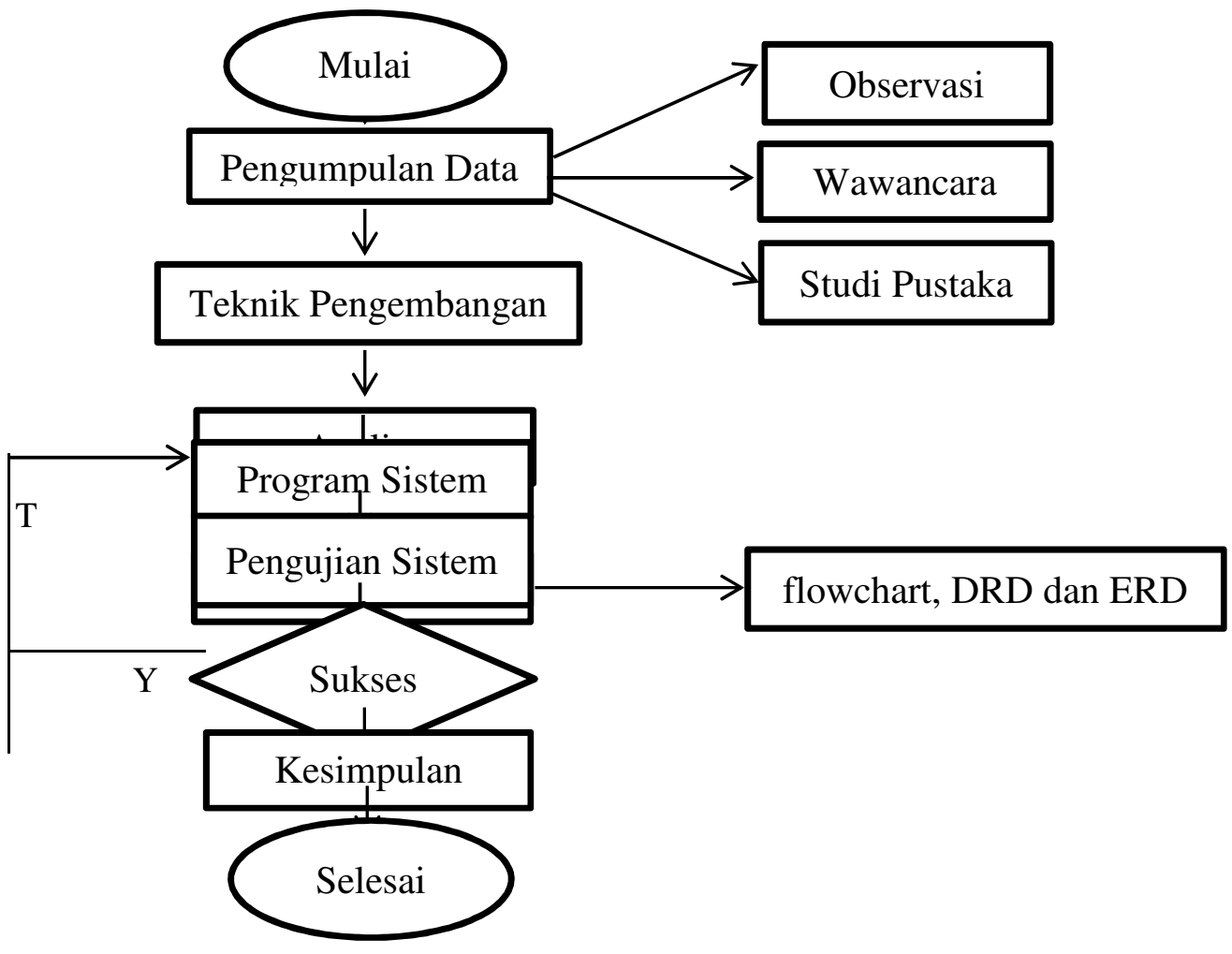

Gambar 1. Kerangka Peneitian

Pada gambar 1 diatas dapat dijelaskan langkah yang dilakukan pada setiap tahapannya. Kerangka penelitian ini dapat dijabarkan sebagai berikut.

\subsection{Teknik Pengumpulan Data}

Metode pengumpulan data adalah teknik atau metode yang digunakan untuk mengumpulkan data. Metode ini menunjukkan suatu cara agar tujuannya dapat ditunjukkan melalui wawancara, dokumen, dan lain-lain [8]. Pada penelitian, teknologi pengumpulan data merupakan faktor yang sangat penting bagi keberhasilan penelitian. Ini melibatkan bagaimana data dikumpulkan, dari siapa, dan alat apa yang digunakan.

\subsection{Teknik Pengembangan}

Teknik pengembangan sistem yang digunakan adalah metode waterfall. Metode air terjun adalah proses pengembangan perangkat lunak berkelanjutan di mana kemajuan dilihat sebagai aliran ke bawah yang berkelanjutan (seperti air terjun) melalui fase perencanaan, pemodelan, implementasi (pembangunan), dan pengujian [9]. 


\subsection{Analisa Kebutuhan Sistem}

Pada tahap ini penulis menganalisis masalah yaitu pelanggan harus membawa secarik kertas ke toko langsung untuk memesan barang yang ingin dipesannya, kemudian menyerahkan kertas tersebut kepada petugas untuk mengambil barang apa saja yang diinginkan pelanggan. Dalam hal ini penulis Ada solusi untuk membuat suatu sistem yang memungkinkan nantinya pelanggan melakukan pemesanan barang secara online melalui website yang bertujuan untuk mempermudah pelanggan dalam memesan atau membeli barang yang mereka inginkan, dan juga dapat mempermudah untuk karyawan toko untuk menyediakannya dalam layanan Toko Hikmah Motor

\subsection{Desain Sistem}

Setelah menganalisis permasalahan yang ada, tahap selanjutnya adalah perancangan sistem. Perancangan sistem dilakukan dengan menggunakan model pemrosesan sistem yang diterapkan, memahami desain informasi yang ada, dan mengimplementasikan model yang dibutuhkan oleh pengguna. Pemodelan sistem merupakan perancangan antarmuka pemrograman aplikasi yang akan diimplementasikan dengan benar.

\subsection{Pengkodean}

Dalam tahap ini dilakukan penulisan kode program yang merupakan penerjemah dari rancangan yang telah dibuat menggunakan perintahperintah pemograman yang dapat dimengerti komputer. Dalam pembuatan aplikasi ecommerce penjualan dan pemesanan sparepart menggunakan bahasa pemograman web.

\subsection{Pengujian Sistem}

Setelah sistem aplikasi dibuat maka dilakukan uji coba terlebih dahulu sebelum diberikan kepada user, jika tidak sesuai dengan apa yang diinginkan user maka sistem tersebut akan direvisi dan dilakukan uji coba kembali, dan pada tahap pengujian ini metode yang digunakan adalah Blacbox Testing.

\subsection{Pemeliharaan system}

Setelah sistem melewati tahap pengujian serta layak untuk digunakan, maka tahapan akhir dalam model waterfall. Perangkat lunak yang sudah jadi, kemudian dijalankan juga dilakukan pemeliharaan. Pemeliharaan termasuk dalam memperbaiki kesalahan yang tidak ditemukan pada tahap-tahap sebelumnya, evaluasi sistem dan pengembangan sistem berdasarkan umpan balik agar sistem dapat tetap berjalan dan berkembang sesuai dengan fungsinya.

\section{HASIL DAN PEMBAHASAN}

\subsection{Hasil Pengumpulan Data}

Hasil pengumpulan data yang dilakukan oleh peneliti mengenai penjualan dan pemesanan sparepart pada toko hikmah motor berbasis web dapat disimpulkan bahwa dalam penjualan dan pemesanan sparepart ini dapat membantu pihak toko dalam penjualan dan juga dapat membantu customer dalam memesan barang, dengan adanya permasalah yang dihadapi pihak toko maupun customer, peneliti melakukan pengumpulan data yang dibutuhkan dengan cara melakukan observasi dan wawancara kepada pemilik toko, berikut tabel 3 hasil wawancara:

Wulandari, et., al [Aplikasi E-Commerce Penjualan dan Pemesanan Sparepart Berbasis Web Menggunakan Framework Codeigniter pada Toko Hikmah Motor] 
Tabel 3. Hasil Observasi

\begin{tabular}{|c|c|}
\hline Uraian Kegiatan & Hasil \\
\hline \begin{tabular}{llr}
\multicolumn{3}{l}{ Mengambil informasi mengenai } \\
proses penjualan dan \\
pemesanan & sparepart di & Toko \\
hikmah motor
\end{tabular} & $\begin{array}{l}\text { Proses penjualan dan pemesanan yang } \\
\text { ada, masih mempunyai banyak kendala } \\
\text { dimana penjual masih menggunakan } \\
\text { aplikasi whatsapp untuk menawarkan } \\
\text { produk yang tersedia. Lalu customer } \\
\text { yang ingin memesan barang harus } \\
\text { datang langsung ke toko dengan } \\
\text { membawa catatan barang apa saja yang } \\
\text { di ingin di pesan, dan harus menunggu } \\
\text { pesanan tersebut hingga selesai. }\end{array}$ \\
\hline
\end{tabular}

Tabel 4. Hasil Wawancara

\begin{tabular}{|c|c|}
\hline Pertanyaan & Jawaban \\
\hline $\begin{array}{l}\text { Bagaimana sistem pelayanan } \\
\text { di toko ini? }\end{array}$ & $\begin{array}{l}\text { Pelayanan masih konvensional dimana } \\
\text { customer yang ingin memesan harus } \\
\text { datang langsung ke toko. }\end{array}$ \\
\hline $\begin{array}{lrr}\text { Bagaimana } & \text { cara } r \text { ketika } \\
\text { customer } & \text { melakukan } \\
\text { pemesanan } & \text { barang di toko } \\
\text { ini? } & & \end{array}$ & $\begin{array}{l}\text { Customer datang langsung dan kadang } \\
\text { ada yang memesan lewat aplikasi } \\
\text { whatshaap. }\end{array}$ \\
\hline $\begin{array}{l}\text { Apa saja kendala yang di } \\
\text { alami ketika customer } \\
\text { melakukan pemesanan? }\end{array}$ & $\begin{array}{l}\text { Ketika customer melakukan pemesanan } \\
\text { lewat aplikasi whatshapp ataupun dengan } \\
\text { datang langsung ketoko kadang salah satu } \\
\text { barang yang di pesen customer habis, } \\
\text { toko kehabisan stok. Hal itu } \\
\text { menyebabkan customer merasa kecewa. }\end{array}$ \\
\hline
\end{tabular}

\subsection{Analisis sistem}

Setelah mengumpulkan data penting mengenai penelitian ini, tahap selanjutnya adalah menganalisis suatu sistem. Menganalisis suatu sistem merupakan suatu proses untuk memahami sistem yang ada bertujuan sebagai dasar perancangan atau perbaikan sistem lama. Dari penelitian yang dilakukan pada Toko Hikmah Motor, dengan menganalisa sistem terdapat beberapa masalah yaitu pada proses penjualan dan pemesanan sparepart yang selama ini masih dilakukan secara konvensional, sehingga mengharuskan customer untuk mendatangi toko dalam melakukan pemesanan, maka perlu untuk dibuatkan sebuah sistem baru yang dapat mempermudah customer dalam melakukan proses pemesanan dan pihak toko dalam melakukan proses pelayanan. Dengan adanya aplikasi ecommerce penjualan dan pemesanan sparepart berbasis web, makan customer bisa melakukan pemesanan dengan mudah dimana saja selama terhubung dengan internet.

\subsection{Bagan Alur Sistem(System Flowchart)}

Bagan alir sistem atau System Flowchart adalah bagian yg menunjukkan arus proses penjualan serta pemesanan pada Toko hikmah Motor berdasarkan sistem yang telah dibuat.

Wulandari, et., al [Aplikasi E-Commerce Penjualan dan Pemesanan Sparepart Berbasis Web Menggunakan Framework Codeigniter pada Toko Hikmah Motor] 
Bagan ini menjelaskan urutan-urutan berasal prosedur-mekanisme yang ada didalam sistem. ilustrasi system flowchart bisa dilihat dari gambar 2 dan gambar 3 sebagai berikut :

a. Flowchart Sistem Lama

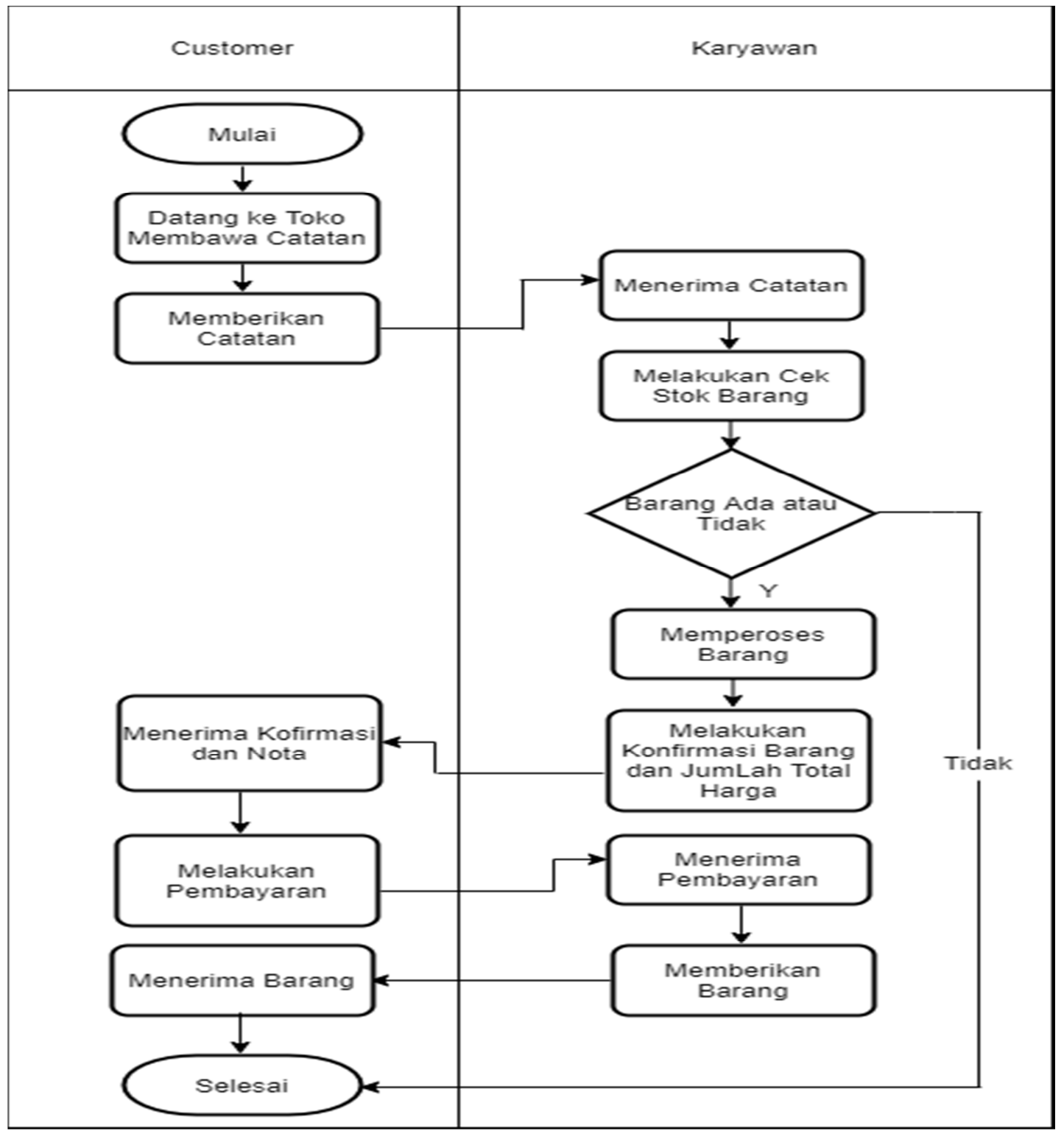

Gambar 2. Flowchart Sistem Lama

b. Flowchart Sistem Baru 


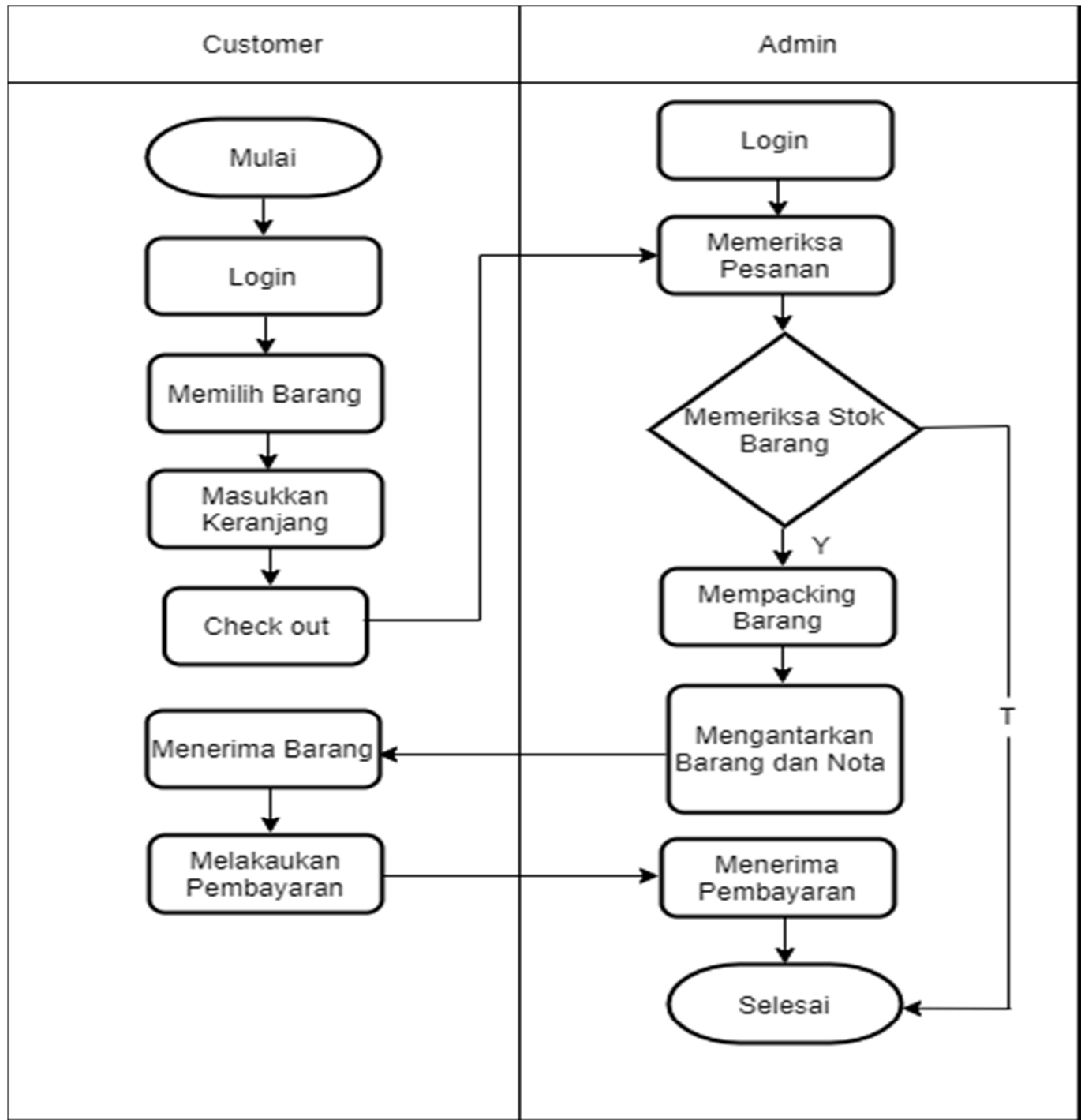

Gambar 3. Flowchart Sistem Baru

\subsection{Diagram Konteks}

Diagram Konteks artinya diagram sederhana yg mendeskripsikan korelasi entity luar, masukan serta keluaran yang berafiliasi menggunakan sistem. Context Diagram untuk sistem penjualan dan pemesanan sparepart di Toko Hikmah Motor sebagai berikut:

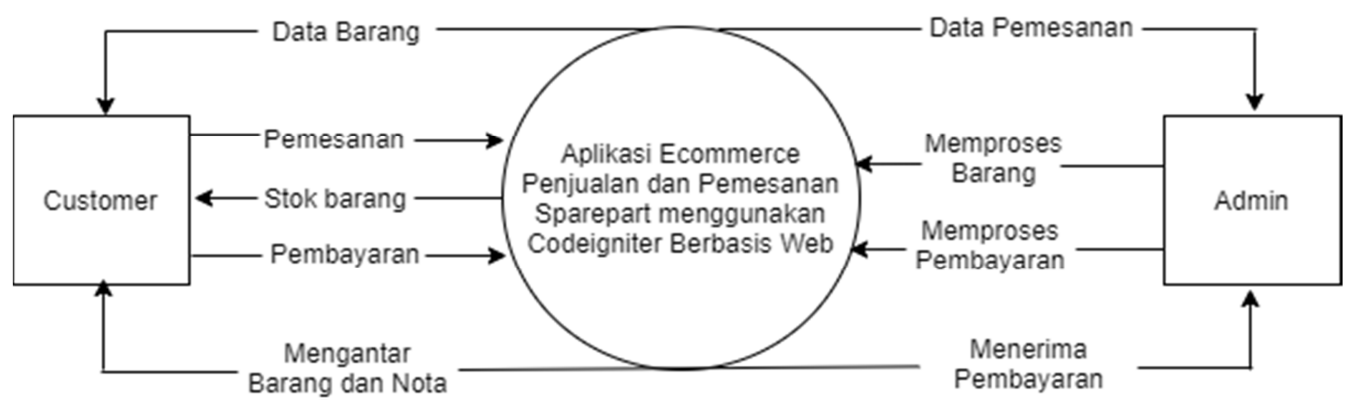

Gambar 4. Context Diagram

Wulandari, et., al [Aplikasi E-Commerce Penjualan dan Pemesanan Sparepart Berbasis Web Menggunakan Framework Codeigniter pada Toko Hikmah Motor] 


\subsection{Bagan Berjenjang}

Setelah pembuatan Diagram Konteks maka dilanjutkan dengan pembuatan Bagan Berjenjang untuk memudahkan pembuatan DFD level level yang lebih bawah. Berikut adalah bagan berjenjang aplikasi ecommerce penjualan dan pemesanan sparepart pada toko Hikmah Motor:

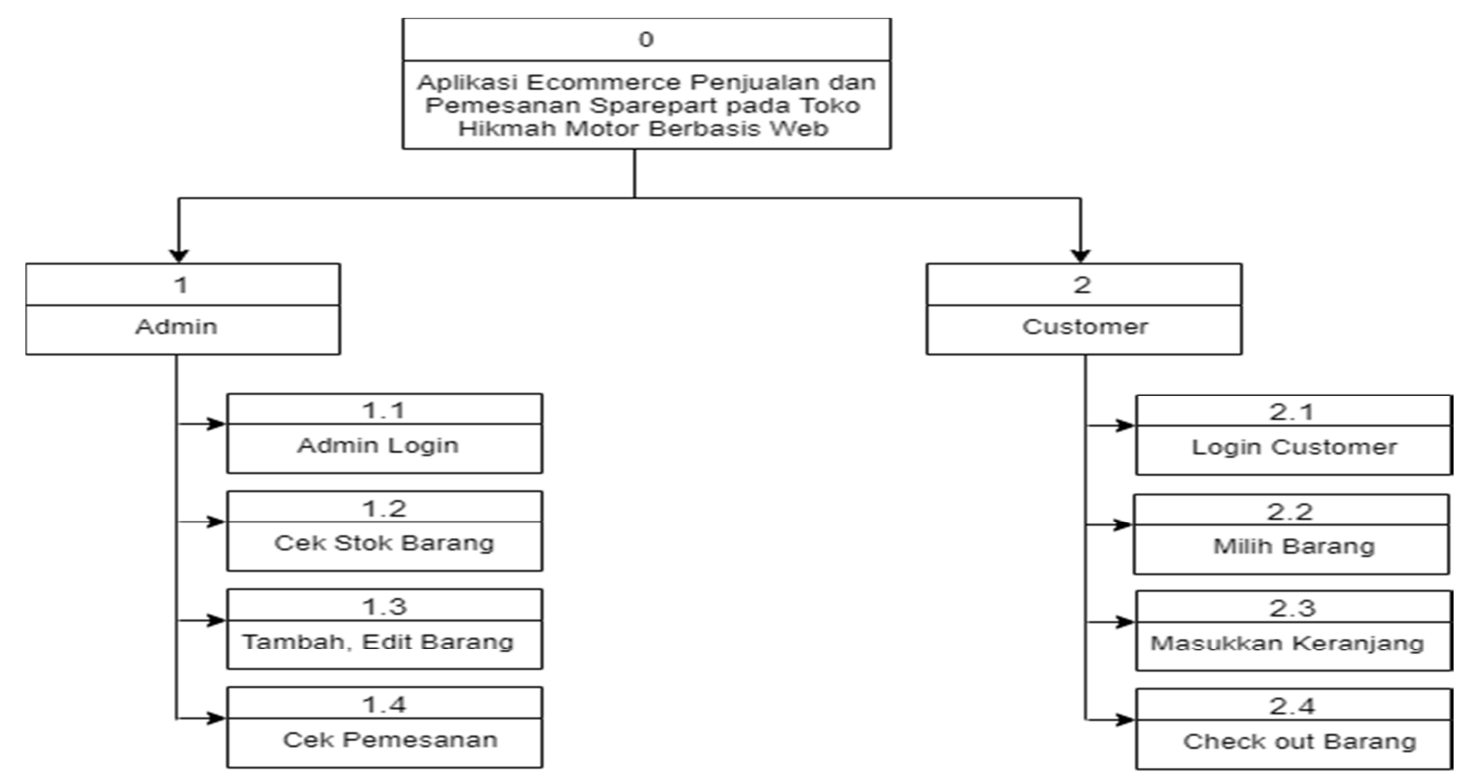

Gambar 5. Bagan Berjenjang

\subsection{DFD (Data Flow Diagram)}

Data Flow Diangram (DFD) yaitu suatu diagram yang digunakan untuk menggambarkan aliran data dari sebuah proses atau sistem. Berikut adalah Data Flow Diagram dari Aplikasi Penjualn dan pemesanan Sparepart pada Toko Hikmah Motor:

a. DFD Level 1

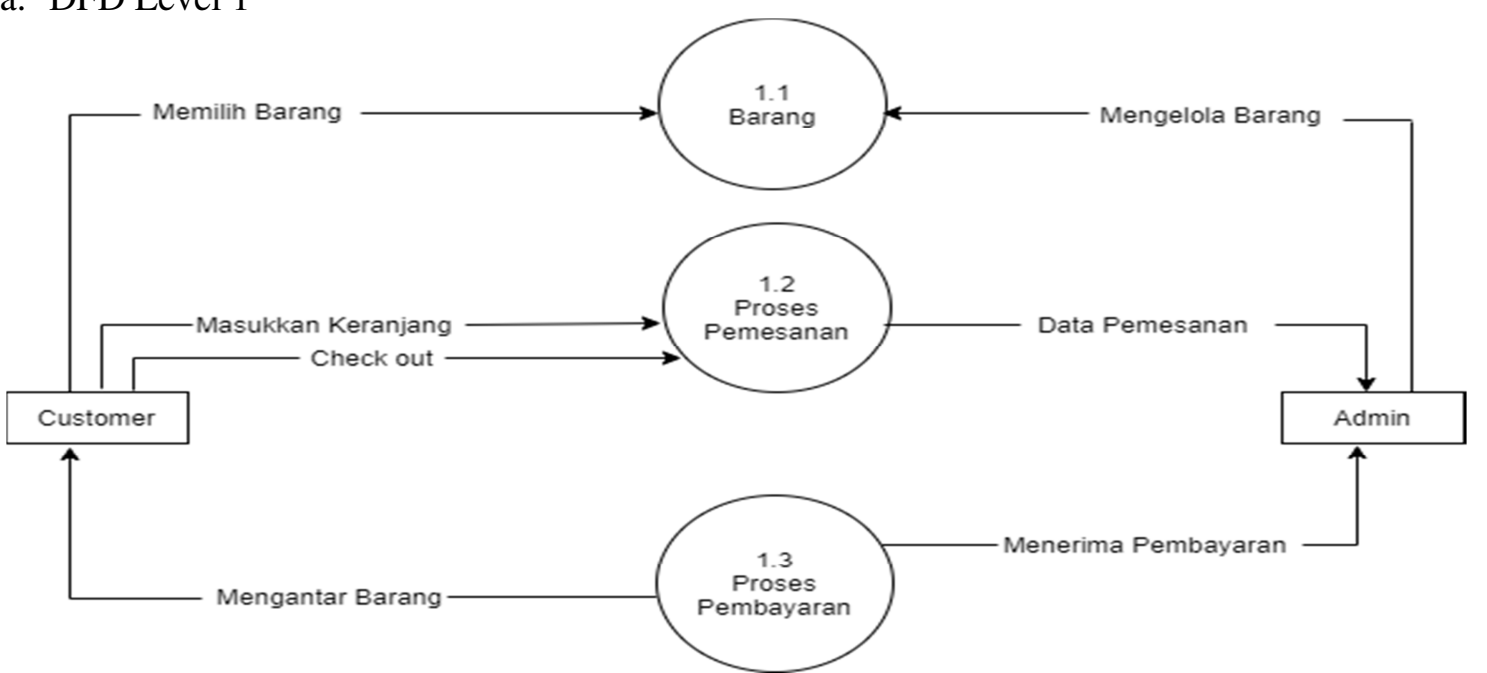

Gambar 6. DFD Level 1

Wulandari, et., al [Aplikasi E-Commerce Penjualan dan Pemesanan Sparepart Berbasis Web Menggunakan Framework Codeigniter pada Toko Hikmah Motor] 
b. DFD Level 1 Proses 1

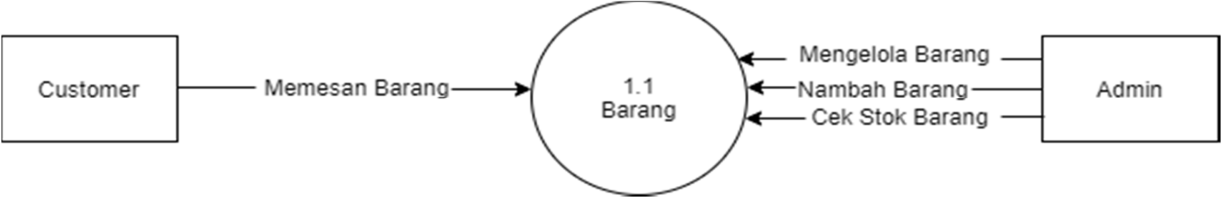

Gambar 7. DFD Level 1 Proses 1

c. DFD Level 1 Proses 2

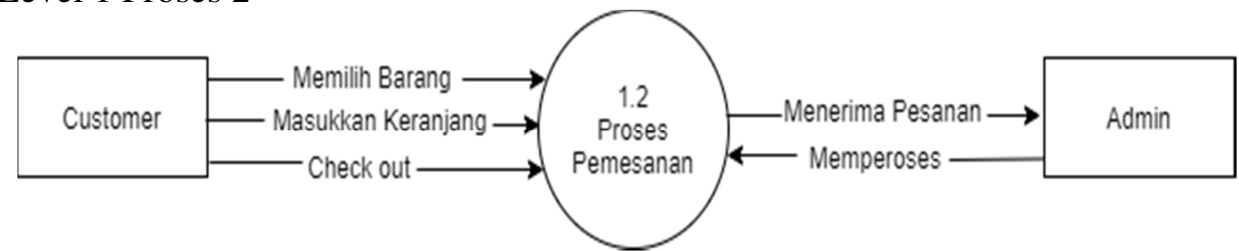

Gambar 8. DFD Level 1 Proses 2

d. DFD Level 1 Proses 3

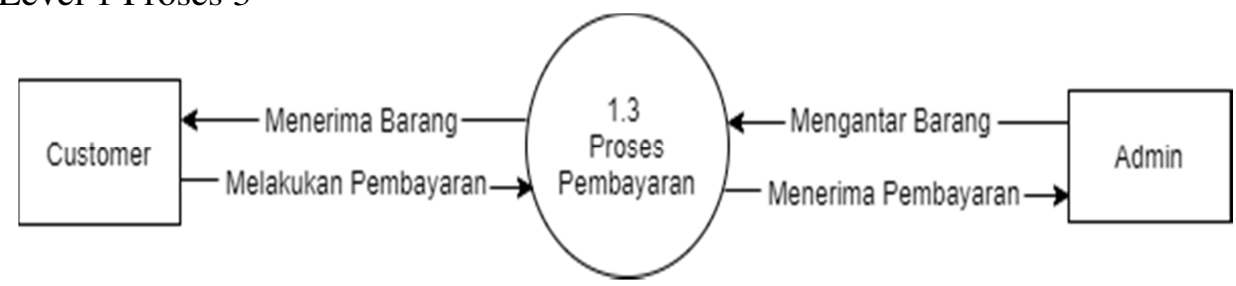

Gambar 9. DFD Level 1 Proses 3

\subsection{ERD (Entity Relationship)}

Entity Relationship (ERD) yaitu suatu relasi yang menggambarkan semua entity yang ada menjadi satu kesatuan yang saling berkaitan. Berikut adalah Entity Relationship dari Aplikasi Penjualan dan Pemesanan Sparepart pada Toko Hikmah Motor:

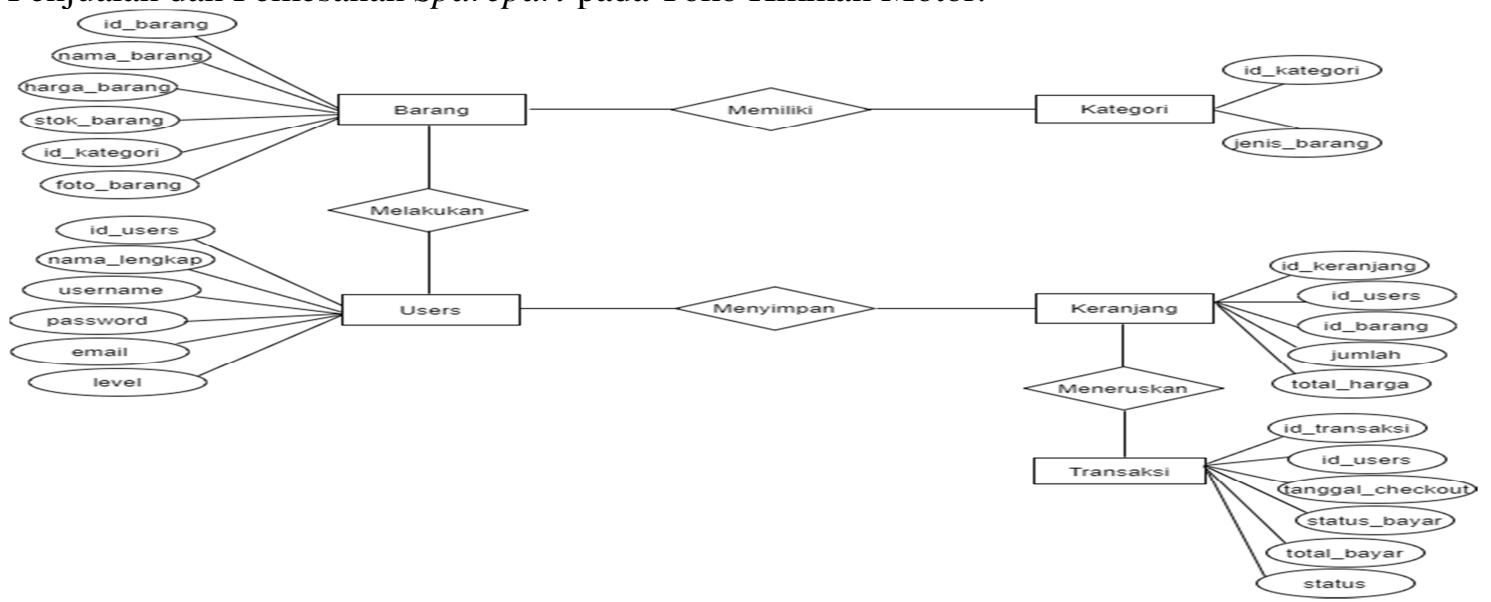

Gambar 10. ERD (Entity Relationship Diagram) 


\subsection{Implementasi Program}

Tampilan Login Admin
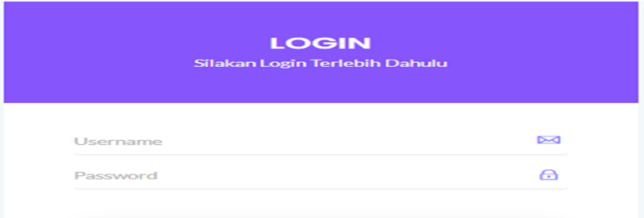

Tampilan Halamn Barang
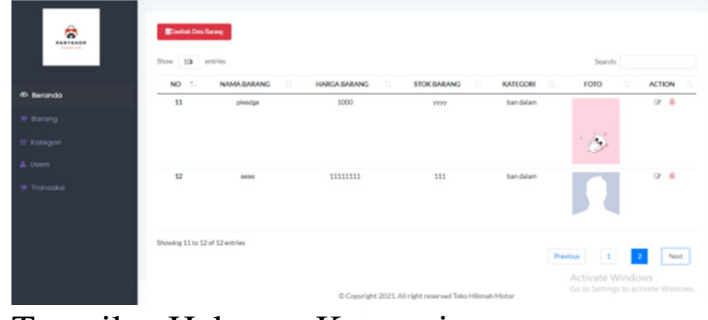

Tampilan Halaman Kategori

Dashboard Beronda/ Kategen
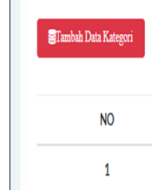

JENISBRPANG bandalem

Tampilan Halaman Users

| Dashboard Beronda / Usess
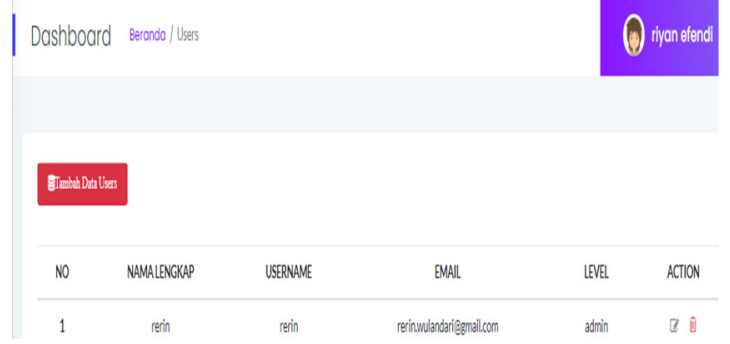

Tampilan Halaman Transaksi

\begin{tabular}{|c|c|c|c|c|c|c|}
\hline No & USERS & TANGGAL CHECKOUT & TOTAL BAARR & STAUISBAYAR & SAlus & ACTON \\
\hline 1 & aæn & 17:07:2021. & Ro:11800000 & bojac & dikikin & 81 \\
\hline 2 & $\mathrm{~g} z \mathrm{mn} !$ & 17.07:2021 & $R p 300000$ & bojad & olikinn & 80 \\
\hline 3 & gேn & 17:07:02012 & Rop11000000 & bogad & olkikin & 8 i \\
\hline 4 & ck & 18077:02021 & Rp 5000000 & belum & porsess & 80 \\
\hline
\end{tabular}

Tampilan Halaman Customer
Tampilan Halaman Administrator

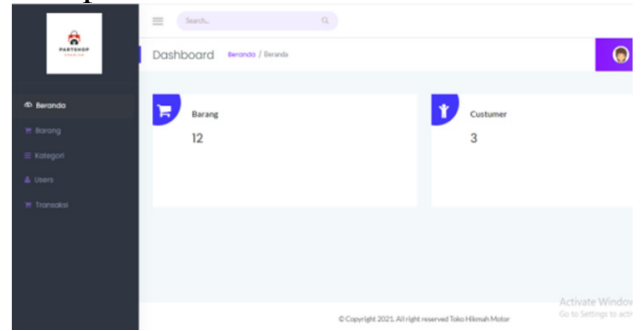

Tampilan Tambah Data Barang

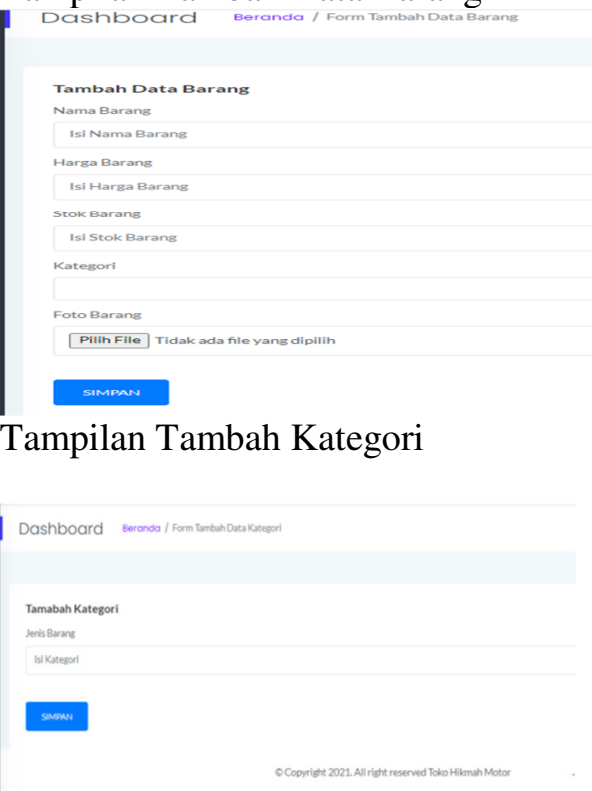

Tampilan Tambah Data Users

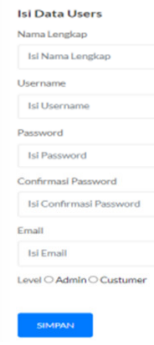

Tampilan Login Customer

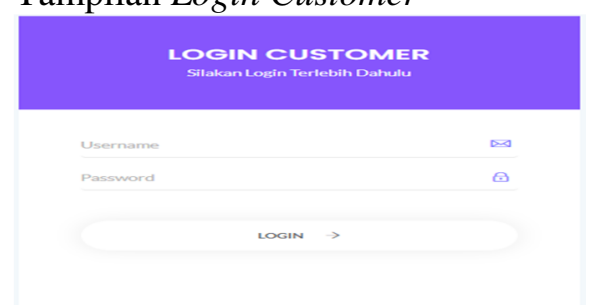




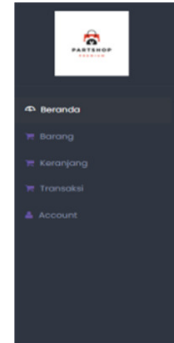

Tampilan Halaman Keranjang

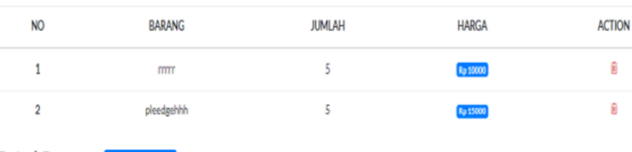

Total Bayar : Rp 25,000

Tampilan Halaman Account

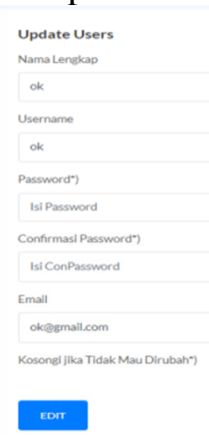

Tampilan Barang Customer

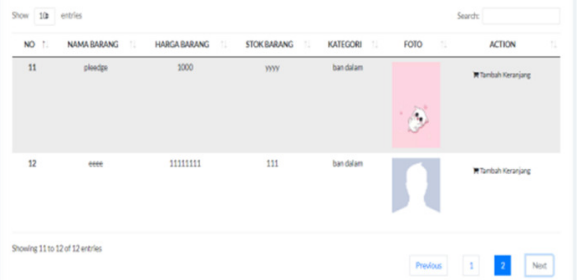

Tampilan Transaksi Customer

Gambar 11. Implementasi

\subsection{Pengujian Program}

Adapun implementasi diatas, pengujian yang dilakukan pada tahap ini adalah sebagai berikut[10] :

Tabel 5. Hasil Pengujian

\begin{tabular}{|c|c|c|c|c|c|c|}
\hline Uraian Pertanyaan & \multicolumn{6}{|c|}{ Kesesuaian } \\
\hline \multirow[t]{2}{*}{ Skor } & SS & ST & $\mathrm{N}$ & $\mathrm{TS}$ & STS & \multirow[t]{2}{*}{ Ket } \\
\hline & 5 & 4 & 3 & 2 & 1 & \\
\hline \multicolumn{7}{|l|}{$\begin{array}{l}\text { Apakah fitur-fitur yag telah dibuat sudah sesuai } \\
\text { dengan kebutuhan } \text { user? }\end{array}$} \\
\hline \multicolumn{7}{|l|}{$\begin{array}{l}\text { Apakah sistem yang telah dibuat dapat bekerja } \\
\text { dengan baik? }\end{array}$} \\
\hline \multicolumn{7}{|l|}{$\begin{array}{l}\text { Apakah user merasa kesulitan dalam } \\
\text { mengoprasikan sistem? }\end{array}$} \\
\hline $\begin{array}{l}\text { Apakah sistem yang telah dibuat dapat } \\
\text { membantu memudahkan user dalam } \\
\text { melakukan penjualan dan pemesanan sparepart } \\
\text { secara online? }\end{array}$ & & & & & & \\
\hline
\end{tabular}

Wulandari, et., al [Aplikasi E-Commerce Penjualan dan Pemesanan Sparepart Berbasis Web Menggunakan Framework Codeigniter pada Toko Hikmah Motor] 
Keterangan :

$\begin{array}{ll}\text { SS } & =\text { Sangat Setuju } \\ \text { S } & =\text { Setuju } \\ \text { KS } & =\text { Kurang Setuju } \\ \text { TS } & =\text { Tidak Setuju } \\ \text { STS } & =\text { Sangat Tidak Setuju }\end{array}$

Adapun hasil perhitungan pengujian aplikasi ecommerce penjualan dan pemesanan sparepart berbasis web di toko hikmah motor yang terdiri dari pemilik toko dan juga customer didapat data sebagai berikut:

Tabel 6. Hasil Pengujian

\begin{tabular}{|c|l|l|l|l|l|l|}
\hline Uraian Pertanyaan & \multicolumn{5}{|c|}{ Kesesuaian } \\
\hline Skor & SS & ST & N & TS & STS & Ket \\
\cline { 2 - 9 } & 5 & 4 & 3 & 2 & 1 & \\
\hline $\begin{array}{l}\text { Apakah fitur-fitur yag telah dibuat sudah sesuai } \\
\text { dengan kebutuhan user? }\end{array}$ & 2 & 1 & & & & \\
\hline $\begin{array}{l}\text { Apakah sistem yang telah dibuat dapat bekerja } \\
\text { dengan baik? }\end{array}$ & & 2 & 1 & & & \\
\hline $\begin{array}{l}\text { Apakah user merasa kesulitan dalam } \\
\text { mengoprasikan sistem? }\end{array}$ & & & & 3 & & \\
\hline $\begin{array}{l}\text { Apakah sistem yang telah dibuat dapat } \\
\text { membantu memudahkan user dalam } \\
\text { melakukan penjualan dan pemesanan sparepart } \\
\text { secara } \text { online? }\end{array}$ & 2 & 1 & & & & \\
\hline Total & 4 & 4 & 1 & 3 & & \\
\hline
\end{tabular}

berikut:

Berdasarkan hasil qustionnaire Testing diatas, maka dapat ditentukan skor sebagai

a. Peroleh nilai : $\sum$ nilai responden

Nilai Hasil Pengumpulan data $=(4 \times 5)+(4 \times 4)+(1 \times 3)+(3 \times 2)=20+16+3+6$

$$
=45
$$

Jumlah nilai ideal diperoleh dari nilai tertinggi $x$ jumlah butir soal $x$ jumlah responden $=5 \times 4 \times 3=60$

Tabel 7. Kategori Penilaian Responder

\begin{tabular}{|l|l|}
\hline \multicolumn{1}{|c|}{ Nilai Presentase } & \multicolumn{1}{c|}{ Interprestasi } \\
\hline $25(\%)$ & Tidak Baik \\
\hline $26-50(\%)$ & Kurang Baik \\
\hline $51-75(\%)$ & Baik \\
\hline $76-100(\%)$ & Sangat Baik \\
\hline
\end{tabular}

Wulandari, et., al [Aplikasi E-Commerce Penjualan dan Pemesanan Sparepart Berbasis Web Menggunakan Framework Codeigniter pada Toko Hikmah Motor] 
Rumus penentuan nilai $=\left(\frac{\text { nilai perolehan }}{\text { nilai ideal }}\right) \times 100=45 / 60 \mathrm{x} 100 \mathrm{x}=75(\%)$

Jadi, hasil dari perhitungan menggunakan metode skala likert ini dapat disimpulkan bahwa aplikasi ecommerce penjualan dan pemesanan sparepart berbasis web di toko hikmah motor ini baik dan layak untuk digunakan oleh customer dalam melakukan pemesanan sparepart secara online.

\section{KESIMPULAN}

Berdasarkan hasil penelitian dan pengujian sistem maka dapat disimpulkan bahwa:

Aplikasi ecommerce penjualan dan pemesanan sparepart berbasis web menggunakan codeigniter pada Toko hikmah motor. Dapat mempermudah pihak toko dalam melakukan penjualan dan pelayanan, juga memepermudah customer untuk melakukan pemesanan sparepart. Berdasarkan hasil penelitian yang dilakukan dengan menggunakan pengujian internal dan eksternal diperoleh nilai 75\% yang dapat disimpulkan bahwa aplikasi tersebut dikategorikan baik dan layak untuk digunakan.

\section{SARAN}

Adapun saran yang dapat penulis sampaikan ialah sebagai berikut:

a. Diharapkan sistem aplikasi ecommerce penjualan dan pemesanan sparepart berbasis web ini dapat digunakan pada Toko hikmah motor.

b. Penelitian selanjutnya diharapkan sistem ini dapat lebih dikembangkan.

\section{UCAPAN TERIMA KASIH}

Penulis sampaikan terima kasih yang sebesar-besarnya kepada pihak Toko yang telah memperkenankan dalam melakukan penelitian dan semua pihak yang telah mendukung, sehingga penulis dapat menyelesaikan Aplikas Ecommerce Penjualan dan Pemesanan Sparepart Berbasis Web Menggunakan Framework Codeigniter pada Toko Hikmah Motor.

\section{DAFTAR PUSTAKA}

[1] Pasaribu, A. F. O., Darwis, D., Irawan, A., \& Surahman, A. 2019. Sistem Informasi Geografis Untuk Pencarian Lokasi Bengkel Mobil di Wilayah Kota Bandar Lampung. Jurnal Tekno Kompak, 13 (2), 1-6.

[2] Welim, Y. Y., Wisjhnuadji, T. W., \& Firmansyah, R. 2015. Pengembangan Sistem Informasi Service Kendaraan pada Bengkel KFMP. Simetris: Jurnal Teknik Mesin, Elektro dan Ilmu Komputer, 6(1), 17-26.

[3] Setyawan, P. 2017. Sistem Informasi Penyediaan Gudang Sparepart Sepeda Motor pada Bengkel Joker Motor Sport (JMS). Artikel Skripsi Universitas Nusantara PGRI Kediri, 19.

Wulandari, et., al [Aplikasi E-Commerce Penjualan dan Pemesanan Sparepart Berbasis Web Menggunakan Framework Codeigniter pada Toko Hikmah Motor] 
[4] Yordan, Y., \& Umagapi, D. 2016. Perancangan Sistem Informasi Penjualan Sparepart Motor pada CV. LION. IJIS-Indonesian Journal On Information System, 1(1).

[5] Widianti, W. 2016. Perancangan Sistem E-Commerce pada Ahass 00244 CV. Akur Motor Pringsewu. Prociding KMSI, 4(1).

[6] Prabowo, W., \& Sutrisno, J. 2019. Perancangan E-Commerce Untuk Penjualan Spareparts pada Bengkel ABM Motor. IDEALIS: InDonEsiA journaL Information System, 2(6), 74-80.

[7] Zubaidah. 2017. Perancangan Sistem Informasi Penjualan Sparepart Motor pada Bengkel One Batam Berbasis Web.

[8] Data, T. P. 2015. Instrumen Penelitian. Kisi-kisi Instrumen.

[9] Nurhidayat, S., \& Rusli, M. 2020. Membangun E-Commerce Spare Parts Mobil pada Toko Aneka Jaya Motor. KALBISCIENTIA Jurnal Sains dan Teknologi, 7(1), 30-30.

[10] Sugiyono, P. 2016. Metode Penelitian Manajemen (Pendekatan Kuantitatif, Kualitatif, Kombinasi (Mixed Methods), Penelitian Tindakan (Action Research, dan Penelitian Evaluasi). Alfabeta, Bandung. 